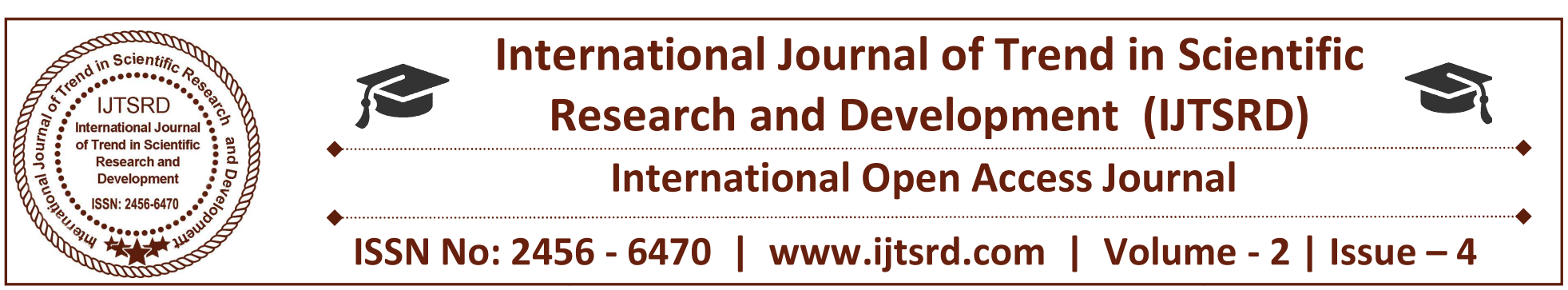

\title{
Micro Finance and Women Empowerment with Special Reference to Self-Help Groups (SHG)
}

\author{
Mr. Abhilash K \\ Faculty of Commerce, Akkamahadevi Women's University, \\ Vijayapura. Ext. PG Studies and Research, Mandya, Karnataka, India
}

\begin{abstract}
The gender inequality existing in the demographic composition of a society is portrayed by the socioeconomic conditions of the female population, their literacy rate, poverty, employment opportunity, life expectancy etc. It is a universally acceptable economic prescription that, for a populous country like India, ready to enjoy the Demographic dividend, gender equality is a main objective that must be achieved in order to achieve sustainable overall economic growth. In this paper we make a humble effort to study the problems associated with gender inequality and the potentiality of microfinance institutions in reducing the gap of gender inequality and ensuring women empowerment.
\end{abstract}

Keywords: Micro-Finance, Non Governmental Organization, Self Help Groups

\section{INTRODUCTION}

India is blessed to enjoy the fruits of Demographic Dividend in the years to come. But, this asset has to be very judiciously and cautiously handled. There are numerous impediments on the path. India has to take care of certain fronts like the gender equity and gender empowerment. A nation where the female population accounts for 48.46 percent of the total population, cannot afford to neglect the issues related to gender inequity and gender empowerment. The gender inequality existing in the society is portrayed by the socio-economic conditions of the female population, their literacy rate, poverty, employment opportunity, life expectancy etc. In this paper we make a humble effort to study the problems associated with gender inequality and the potentiality of

microfinance institutions in reducing the gap of gender inequality and ensuring women empowerment.

Financial inclusion has become a major policy theme of the Government of India. Financial inclusion is seen as an important underpinning for economic growth as well as a means of enabling broader participation in the economy and more equitable development. While the term came into widespread use with policies introduced in 2005 , the history of efforts to extend banking services to rural areas began decades earlier. With the launch of the Swabhimaan Financial Inclusion Campaign in 2011 under the banner "taking banking the last mile," the government aimed to give additional momentum to reach all habitations with populations of over 2,000 with at least a branchless means of banking by 2012 . The objective is to increase access to various financial services for individuals and households especially women and marginalized section of society through micro-finance and SHGs (including savings, transmittal of remittances, insurance, and credit).Better access to banking services and credit is also intended to support the needs of micro, small, and medium-sized enterprises (MSMEs), which are also viewed as critical to inclusive growth of women.

\section{MICRO-FINANCE \\ AND \\ WOMEN \\ EMPOWERMENT}

Microfinance is the provision of financial services to low-income clients, including consumers and the self employed, who traditionally lack access to banking and related services. Microcredit, or microfinance, is banking the unbankables, bringing credit, savings and other essential financial services within the reach of 
millions of people who are too poor to be served by regular banks, in most cases because they are unable to offer sufficient collateral. In general, banks are for people with money, not for people without are based on the premise that the poor have skills which remain unutilized or underutilized. Microcredit fits best to those with entrepreneurial capability and possibility. Ultimately, the goal of microfinance is to give low income people an opportunity to become selfsufficient by providing a means of saving money, borrowing money and insurance. The main aim of microfinance is to empower women as they are the most vulnerable and investing in women helps empowering them and contributes to greater economic growth and development. It is revealed in literature that increase in women's resources results in the wellbeing of the family [1]. Impact of microfinance on empowerment of women has given mixed results. According to Le and Raven [2], microfinance has helped many women in their businesses, but has a limited effect on empowering women, creating upward mobility and contributing to long-term economic growth. In Indian context, microfinance was found to have a positive influence on women's social capital and normative influence as the make up a large proportion of microfinance beneficiaries. Therefore, facilitating women's collective empowerment [3]. According to Hussain and Nargis [4] the longer a woman participates in microcredit programs, the more employment opportunities she has. Further there is more scope that she may decide to buy productive and non-productive assets. Further, microfinance provides women with the financial banking they need to start business ventures and actively participate in the economy. It gives them confidence, improves their status and makes them more active in decision-making, thus encouraging gender equality. According to CGAP, long-standing MFIs even report a decline in violence towards women since the inception of microfinance. The most of the microcredit institutions and agencies all over the world focuses on women in developing countries. Observations and experience shows that women are a small credit risk, repaying their loans and tend more often to benefit the whole family. In another aspect it's also viewed as a method giving the women more status in a socioeconomic way and changing the current conservative relationship between gender and class when women are able to provide income to the household. There are many reasons why women have become the primary target of microfinance services.
A recent World Bank report confirms that societies that discriminate on the basis of gender pay the cost of greater poverty, slower economic growth, weaker governance, and a lower living standard for all people. At a macro level, it is because 70 percent of the world's poor are women. Women have a higher unemployment rate than men in virtually every country and make up the majority of the informal sector of most economies. They constitute the bulk of those who need microfinance services. Giving women access to microcredit loans therefore generates a multiplier effect -women to have access to financial and economic resources, significant role in household decision making, have greater social networks, have greater communication in general and knowledge about family planning and parenting concerns and have greater freedom of mobility that increases the impact of a microfinance institutions activities, benefiting multiple generations.

\section{MICRO-FINANCE THROUGH SHGS FOR EMPOWERING WOMEN}

NABARD explains that the Self Help Group is a group with "an average size of about 15 people from a homogenous class. They come together for addressing their common problems. They are encouraged to make voluntary thrift on a regular basis. They use this pooled resource to make small interest bearing loans to their members. The process helps them imbibe the essentials of financial intermediation including prioritization of needs, setting terms and conditions and accounts keeping. This gradually builds financial discipline in all of them. They also learn to handle resources of a size that is much beyond the individual capacities of any of them. The SHG members begin to appreciate that resources are limited and have a cost. Once the groups show this mature financial behavior, banks are encouraged to make loans to the SHG in certain multiples of the accumulated savings of the SHG. The bank loans are given without any collateral and at market interest rates. The groups continue to decide the terms of loans to their own members. Since the groups „own accumulated savings are part and parcel of the aggregate loans made by the groups to their members, peer pressure ensures timely repayments." Many, though not all, SHG members are women, possibly as many as $90 \%$. Women also predominate among MFI clients, though their representation seems to differ by type of institution. Therefore, Women empowerment through self help group constitutes an emerging and fast growing trend towards social and economic development of the 
nation. Self Help Groups (SHGs) are one of the innovative and much needed schemes to accelerate the women entrepreneurship, women's self employment and women empowerment. Government also provides various financial and non-financial assistance to promote the Self Help Groups for women empowerment. Banks and financial institutions have also realized the impact of the Self Help Groups. Hence they are channelizing their funds for women and rural development through Self Help Groups.

Women Activities Under Various Self Help Group Schemes Women Self Help Groups were formed based on the motives like social and economic welfare, awareness of women's rights and duties, building leadership qualities, skill development, etc. Women Empowerment and Poverty Reduction Project were launched to reduce poverty and empower the women. Apart from regular savings, Self Help Groups are engaged in business activities to uplift themselves financially and economically. Self Help Groups in the state are engaged in giving training for sewing, coir knitting and sale, manufacturing of soaps, manufacturing of toys and wires, manufacturing of blue, bringing up of mushrooms etc. Many workshops were conducted for the welfare and awareness of self help group members and people community. Watershed development, Agricultural extension, Health and Sanitation programmes, AIDS awareness programmes, Family welfare programmes etc., are some of the vital activities in this context. Public distribution scheme outlets are also run by Self Help Groups in India. Self-help groups (SHGs) movement has triggered off a silent revolution in empowering women. And have proved as an effective medium for delivering credit to women for their socioeconomic empowerment.

\section{CONCLUSION}

Empowering women is the main social objective of microfinance programs. It is difficult to evaluate the effectiveness of microfinance program on women empowerment because measurement of women empowerment is a difficult task. Microfinance is a powerful tool in enhancing women empowerment for its all indicators like household economic decision making, economic security, family decision making, mobility and legal awareness. Only participation in microfinance program does not lead to increase in women empowerment but when it is coupled with participation in seminars, workshops and training then it helps women in enhancing their empowerment.
These training programs not only provide selfemployment training but also facilitate good decisionmaking.

\section{REFERENCES}

1) Abdul Raheem, aphyasmeen and solthana kissan (2007), World empowerment of women thought self help group a view sakthi sugans Ltd, p. 48.

2) Arjun Y. P. (2010). Women SHG Programmes and Rural Poverty: A Micro Study. Southern Economist. 47-50.

3) Hussain, G., \& Nargis, N. (2008). A welfare economic analysis of the impact of microfinance in Bangladesh. Department of Economics, University of Dhaka, Nilkhet, Dhaka-1000, Bangladesh.

4) Jayaraman, R. (2005). Performance analysis of fisherwomen self help groups in Tamilnadu. THOOTHUKKUDI-628, 8 .

5) Kabeer, N. (1999). Resources, agency, achievements: Reflections on the measurement of women's empowerment. Development and change, 30(3), 435-464.

6) Le, Q. V., \& Raven, P. V. (2015). Woman entrepreneurship in rural Vietnam: Success and motivational factors. The Journal of Developing Areas, 49(2), 57-76.

7) Narang, U. (2012). Self Help Group: An Effective Approach to Women Empowerment in India. International Journal of Social Science and Interdisciplinary Research, 1(8), 8-16.

8) Parida, P. C., \& Sinha, A. (2010). Performance and sustainability of self-help groups in India: A gender perspective. Asian Development Review, 27(1), 80 .

9) Sanyal, P. (2009). From credit to collective action: The role of microfinance in promoting women's social capital and normative influence. American Sociological Review, 74(4), 529-550.

10) Shastri, R. K. (2009). Micro finance and poverty reduction in India (A comparative study with Asian Countries). African Journal of Business Management, 3(4), 136.

11) Shastri, R. K. (2009). Micro finance and poverty reduction in India (A comparative study with Asian Countries). African Journal of Business Management, 3(4), 136.

12) Vinodhini, R. L., \& Vaijayanthi, P. (2016). Selfhelp group and socio-economic empowerment of women in rural India. Indian Journal of Science and Technology, 9(27). 


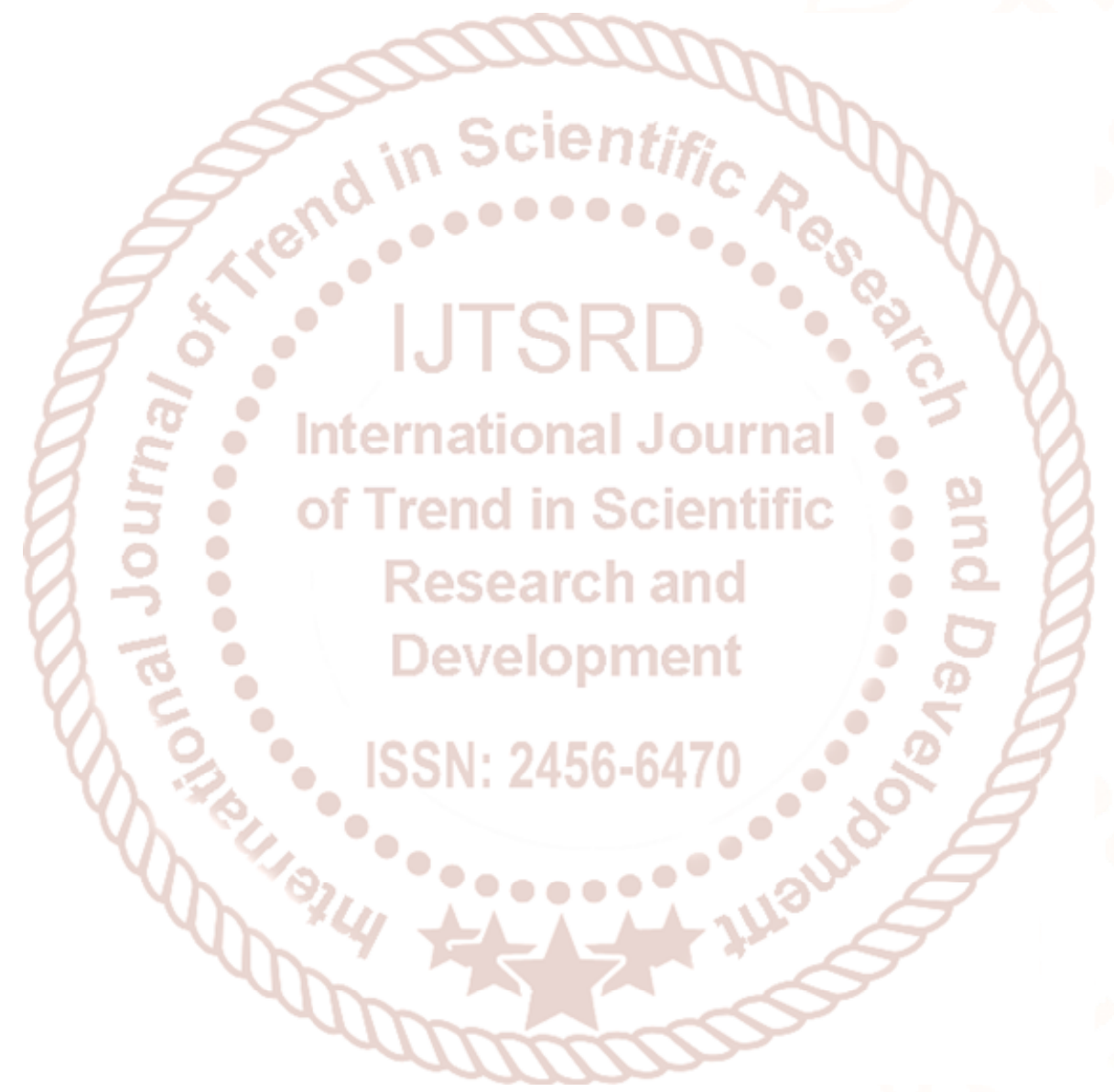

